\title{
ESCOLARIZAÇÃO DE JOVENS E IGUALDADE NO EXERCÍCIO DO DIREITO À EDUCAÇÃO NO BRASIL: EMBATES DO INÍCIO DO SÉCULO XXI*
}

\author{
Marcio Pochmann ${ }^{1}$ \\ Eliza BARTOLOZZI FerReira ${ }^{2}$
}

\begin{abstract}
RESUMO: Este texto objetiva examinar a concepção das políticas de democratização da escolarização dos jovens, desenvolvida no início deste século. Os dados e as análises apresentados, que fazem parte de uma pesquisa mais ampla que conta com financiamento do Conselho Nacional de Desenvolvimento Científico e Tecnológico $(\mathrm{CNPq})$, constituem duas sessóes principais. A primeira é voltada à reflexão da inclusão dos jovens à escolarização básica e superior como resultado de políticas construídas sobre o princípio da desigualdade legítima e não sob o princípio da equidade no acesso aos direitos a partir de abordagens teóricas que discutem o movimento histórico atual do novo espírito do capitalismo. A segunda sessão, assentada no estudo empírico das informações primárias sistematizadas e selecionadas do banco de dados do Instituto Brasileiro de Geografia e Estatística (IBGE), interpreta a situação recente da escolaridade dos jovens de 15 a 29 anos de idade e suas taxas de ocupaçáo na vida social. $O$ argumento desenvolvido é de que as políticas educacionais para os jovens são resultado de medidas de adequação da educação brasileira à lógica da competitividade instaurada no capitalismo global, com características marcadas pela busca de um suposto equilíbrio inclusão/exclusão vis-à-vis à histórica limitação das ações governamentais direcionadas à igualdade dos direitos.
\end{abstract}

Palavras-chave: Educação. Igualdade. Direitos. Jovens. Política. Capitalismo.

\footnotetext{
*Projeto de pesquisa "Programa Ensino Médio Inovador: condições de trabalho e formaçáo docente", processo número 482975/2013-0 (Conselho Nacional de Desenvolvimento Científico e Tecnológico - CNPq; pesquisa de pós-doutoramento "As políticas de ensino médio sob o olhar da sociologia da açáo pública, processo número 99999. 001570/2014-05 (Coordenação de Aperfeiçoamento de Pessoal de Nível Superior - CAPES).

${ }^{1}$ Universidade Estadual de Campinas (Unicamp), Instituto de Economia, Centro de Estudos Sindicais e de Economia do Trabalho - Campinas (SP), Brasil.

${ }^{2}$ Universidade Federal do Espírito Santo, Programa de Pós-graduação em Educaçáo, Centro de Educação Vitória (ES), Brasil. E-mail: eliza.bartolozzi@gmail.com

DOI: 10.1590/ES0101-73302016160477
} 


\title{
EDUCATION OF YOUNG PEOPLE AND EQUALITY IN THE EXERCISE OF THE RIGHT TO EDUCATION IN BRAZIL: CLASHES OF THE EARLY TWENTY-FIRST CENTURY
}

\begin{abstract}
This paper aims to examine the design of youth education democratization policies developed at the beginning of the century. The data and analysis presented, which are part of a broader research that is funded by the National Council for Scientific and Technological Development (CNPq), form two main sessions. The first aimed to reflect the inclusion of young people into basic and higher education as a result of policies constructed on the principle of legitimate inequality and not on the principle of equal access to rights from theoretical approaches to discuss the current historical movement of the new spirit of capitalism. The second session, seated in the empirical study of systematized and selected primary information from the Brazilian Institute of Geography and Statistics (IBGE) database, interprets the recent situation of the education of young people, 15 to 29 years old, and their occupancy rates in social life. The argument is that education policies for young people are the result of adaptation measures of Brazilian education to the logic of competitiveness brought in global capitalism, with features marked by the pursuit of a supposed inclusion/exclusion balance in relation to the historical limitation of governmental actions aimed at equal rights.
\end{abstract}

Keywords: Education. Equality. Rights. Youth. Politics. Capitalism.

\section{LA SCOLARISATION DES JEUNES ET L'ÉGALITÉ DANS L'EXERCICE DU DROIT À L'ÉDUCATION AU BRÉSIL: LES LUTTES DU DÉBUT DU SIÈCLE XXI}

RÉSUMÉ: Ce texte a le but d'examiner la conception des politiques de démocratisation de la scolarisation des jeunes développées dans le début de ce siècle. Les données et les analyses présentées appartiennent à une recherche plus complexe qui a le soutien financier du Conseil national du développement scientifique et technologique $(\mathrm{CNPq})$ et sont constituées de deux parties principales. La première concerne la réflexion que l'inclusion des jeunes à l'éducation de base et l'enseignement supérieur est le résultat des politiques crées sur le principe de l'inégalité légitime et pas sur le principe de l'égalité à l'accès aux droits à partir des démarches théoriques lesquelles discutent le mouvement historique actuel du nouveau esprit du capitalisme. La deuxième partie est basée sur l'étude empirique des informations primaires organisées et sélectionnées de la base de données de l'Institut brésilien de géographie et statistique (IBGE) et explique la situation présente de la scolarité des jeunes de 15 à 29 ans et leurs pourcentages d'occupation à la vie sociale. Le raisonnement développé indique que les politiques éducationnelles pour les jeunes sont le résultat de mesures d'adéquation de l'éducation brésilienne à la logique de la compétitivité installée par le capitalisme global, bien que des caractéristiques de recherche d'un prétendu équilibre entre inclusion et exclusion face à la limitation historique des actions gouvernementales qui visent l'égalité des droits.

Mots-clés : Éducation. Égalité. Droits. Jeunes. Politique. Capitalisme. 


\section{Introdução}

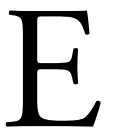

m geral, muitas das políticas públicas em curso neste começo de século surgiram com o objetivo de assegurar a inclusão social dos pobres ao sistema educacional. Especificamente em relação aos jovens, o direito à educação tomou forma de lei e a democratização escolar se configurou como uma expansão massificada. Podemos entender esse movimento como parte do desenvolvimento do capitalismo no Brasil, que necessita incorporar e engajar a população sob o risco de aprofundar os grandes desequilíbrios e gerar conflitos mais intensos. Parte da literatura sobre políticas educacionais denuncia a forma massificada que o direito vem chegando aos jovens, reduzindo o processo formativo à lógica competitiva e individualista. Certamente, essa proposta reforça o tratamento desigual da escola, evidenciando os mecanismos que operam a discriminação dos alunos.

Em comparação com os países membros da Organização para a Cooperação e Desenvolvimento Econômico (OCDE), ainda é longa a trajetória para o alcance do direito à educação plena no Brasil, uma vez que a igualdade de oportunidades se constitui como pressuposto fundamental do direito à educação ${ }^{1}$. De acordo com Cury (2002), a educaçáo, por constituir um serviço público, ainda que ofertado também pela iniciativa privada, é obrigação do Estado interferir no campo das desigualdades sociais e no terreno das hierarquias sociais como fator de redução das primeiras e eliminação das segundas.

Contudo, a democratização da escolarização, promovida pela Constituição Federal de 1988 e regulamentada desde a década de 1990 no Brasil, não reduziu significativamente as desigualdades intra e extraescolares e nem eliminou as hierarquias sociais. Avanços importantes foram constatados, como na descentralização das açóes educacionais, na reorganização dos recursos orçamentários, na ampliação quantitativa de escolas e vagas, na introdução do piso nacional de remuneração, entre outras.

Apesar disso, a trajetória da democratização se revelou muito mais uma expansão quantitativa de matrículas em contextos escolares desiguais e empobrecidos, com trabalhadores desvalorizados como categoria profissional. Portanto, não se construiu uma estrutura para exercer, com igualdade, o direito à educação.

$\mathrm{Na}$ análise da literatura internacional referenciada ao longo deste texto, a questão central hoje não está mais na busca da igualdade, mas na luta contra a exclusão (DEROUET, 2003). Essa é a perspectiva de justiça social que orienta a educação no quadro da globalização econômica e cultural, a qual apresenta uma dinâmica mais acelerada na produção e na circulação das mercadorias. Quadro esse que deixa o trabalho (e os jovens trabalhadores) cada vez mais fragmentado em diversas ocupaçóes distribuídas na área dos serviços. 
Este texto objetiva examinar a concepção das políticas de democratização da escolarização dos jovens desenvolvida neste início do século, sob o argumento de que essas políticas são resultado de medidas de adequação da educação brasileira à lógica da competitividade instaurada no capitalismo global, com características marcadas pela busca de um suposto equilíbrio inclusão/exclusão vis-à-vis à histórica limitação das políticas voltadas para a igualdade dos direitos. Essa problemática é aqui analisada no quadro do terceiro e novo espírito do capitalismo (BOLTANSKI; CHIAPELLO, 2009) ${ }^{2}$, compreendido como a ideologia construída para justificar o engajamento no capitalismo. Essa ideologia começou a se manifestar durante os anos 1980, marcados pelas empresas em rede, a internet e a biotecnologia, a economia global e uma mudança da relação com o dinheiro e com o trabalho, agora caracterizado por trajetórias profissionais marcadas pela flexibilidade e mobilidade. Trata-se de uma visão "conexionista" do mundo social, fundada sobre o projeto ${ }^{3}$ e sobre a avaliação de indivíduos de modo a comprovar a qualidade de suas competências.

O Estado, no novo espírito do capitalismo, em geral, adota políticas que apontam para critérios de justiça; pois os capitalistas, segundo Boltanski e Chiapello (2009), passaram a incorporar as críticas anticapitalistas para conseguir engajar as pessoas indispensáveis à busca da acumulação. Dada a exigência de justificaçôes do sistema para responder às críticas que denunciam o caráter injusto de uma situação, as organizações sociais adotam como referência as convenções de validade geral quanto àquilo que é justo ou injusto ${ }^{4}$. No Brasil, Telles (1999) delimita o período após o regime da ditadura militar, em que a questão social ganha dimensão institucional como "dívida social" a ser resgatada para que o país alcance o projeto de modernidade. Após a Constituição Federal de 1988, diversas noçôes de justiça social passaram a orientar a elaboração de políticas públicas e, com a eleição de um governo popular e democrático (2003-2014), essas noções de justiça estimularam a ampliação da legislação em favor do direito à educação.

Certamente a educação ocupa um lugar de destaque na agenda da sociedade, visto que desempenha um papel decisivo na formação da coesão e integração social $^{5}$. Ela pode ajudar a consolidar um bem comum, já que tem o trabalho de mobilizar a razão dos sujeitos para sua participação na gestão dos assuntos da comunidade. Ademais, o diploma legitima a concorrência, a condição do emprego e a justificação do não emprego.

Nesse contexto, é importante identificar os princípios de justiça que perpassam as políticas educacionais como forma de estabelecer a crítica e também subsidiar projetos mais centrados na superaçáo das desigualdades intra e extraescolares. Compreender as políticas de inclusão dos jovens como seres escolarizados implantadas nos dias atuais exige situar, no plano mais geral, a racionalidade dominante que caracteriza a dialética inclusão/exclusão; igualdade/desigualdade. Por sua vez, a defesa do pluralismo que perpassa a noção de justiça social pode levar a determinados relativismos que inibem ou limitam os valores como, por exemplo, a igualdade. 
É importante enfatizar a abordagem que este texto traz sobre a igualdade. $\mathrm{Na}$ educação, a igualdade não é concebida como um princípio abstrato, mas como uma crítica às desigualdades. Pensar uma educação igual não é desejar uma igualdade perfeita, que é utópica; mas é querer reduzir uma parte das desigualdades em face à instrução, que podem ser ligadas ao território onde se vive, à origem social, ao sexo, à religião etc. As diferenças de condições entre os indivíduos não devem ser definitivas. Somente a igualdade em direitos é definitiva e o objetivo de uma sociedade justa é dar a possibilidade, a cada um, de escolhas e de encontros com o novo. As diferenças sociais não devem ser ligadas nem à nascença, nem à fortuna dos pais, nem aos hábitos culturais, nem à religiáo, nem ao sexo, nem à cor da pele etc. Todas as discriminaçôes devem ser combatidas. A igualdade de direitos deve garantir o poder da escolha para cada cidadão. Por sua vez, a justiça é aquela alicerçada na contribuição das pessoas ao bem comum.

Os dados e as análises desenvolvidas neste texto fazem parte de uma pesquisa mais ampla, financiada pelo Conselho Nacional de Desenvolvimento Científico e Tecnológico (CNPq). Além desta apresentação e consideraçôes finais, este trabalho conta com duas seçóes, sendo o objetivo da primeira a reflexão a partir de abordagens teóricas que discutem o movimento histórico atual do novo espírito do capitalismo, no qual a inclusão dos jovens à escolarização básica e superior é resultado de políticas construídas sobre o princípio da desigualdade legítima e não sob o princípio da igualdade do exercício dos direitos. Na segunda seção são apresentados dados coletados na base do Instituto Brasileiro de Geografia e Estatística (IBGE) com cruzamento de análises para se compreender a situação da escolaridade dos jovens de 15 a 29 anos de idade e suas taxas de ocupação na vida social.

\section{Justiça e exclusão: como esses conceitos podem interpretar as políticas educacionais para os jovens brasileiros}

Neste início do século XXI, a educação brasileira apresenta trajetória inclusiva muito distinta da evidenciada há cem anos. $\mathrm{O}$ abandono do Império pela emergência da instalação da República em 1889 não foi acompanhado de um dos princípios fundamentais das democracias modernas associados ao pleno direito à educação. Muito pelo contrário, a educação escolar ficou restrita a uma pequena elite e, quando expandida, ainda de forma limitada, foi para atender estritamente às exigências da formaçáo de mão de obra para o setor produtivo.

Com a Revoluçáo de Trinta, mudanças importantes podem ser constatadas na orientação do papel do Estado, capazes de viabilizar o sitema educacional brasilerio. Mas foi com a Constituição Federal de 1988 que o país conseguiu avançar para uma concepção ampla de educação como processo de formação humana e sua inscrição como direito social inalienável, bem como a partilha de responsabilidade na oferta escolar entre os entes da federação e a vinculação dos recursos financeiros. 
Nesse sentido, assiste-se a partir dos anos 1990 a universalizaçáo do princípio do acesso de milhares de crianças e jovens à escola. Não obstante os avanços conquistados nesses últimos decênios, a dívida social que o país tem com sua população ainda é muito alta, porque são milhôes de jovens fora da escola, ou incluídos na escola mas excluídos dos seus benefícios. Em 2013, por exemplo, menos da metade das pessoas com 15 anos de idade tinham o diploma de ensino fundamental.

Os últimos anos mostram uma estabilização das matrículas no ensino médio, entre 9,6 e 10,0 milhóes de matrículas nas redes pública e privada. Essa quantidade de matrículas está aquém do que seria o desejável, uma vez que a proporção de jovens de 18 a 29 anos que concluiu esse nível de ensino ainda é baixa. De acordo com a Pesquisa Nacional por Amostra de Domicílios (PNAD) (IBGE, 2013), apenas 58\% dos jovens nessa faixa etária haviam concluído a última etapa da educação básica. Portanto, em 2013, cerca de 16 milhóes de jovens brasileiros não se encontravam formalmente habilitados a pleitear uma vaga na educação superior, pelo fato de náo disporem do requisito legal, ou mesmo a buscar uma melhor inserção no mercado de trabalho (IPEA, 2015).

$\mathrm{Na}$ faixa etária de 18 a 24 anos de idade, $31 \%$ dos jovens não haviam concluído o ensino médio e não estavam estudando. Dependendo da cor ou raça, a realidade dos jovens sofre alteração. Exemplo é o acesso ao ensino superior: do total de estudantes brancos de 18 a 24 anos, $69,4 \%$ frequentavam o ensino superior. Mas entre os jovens estudantes pretos ou pardos, apenas 40,7\% cursavam o mesmo nível (IBGE, 2013).

Não obstante os avanços significativos conquistados no campo da escolarização dos jovens neste início de século, as desigualdades e as hierarquias sociais e escolares permanecem como marca histórica do país. É sabido que o Brasil tem uma trajetória histórica difícil e sinuosa, pois nascido colônia e constituído por forte hierarquia racial e social, a igualdade não foi o princípio que orientou os direitos sociais quando no início do século XX.

Como agravante, o grande acúmulo de riqueza ${ }^{6}$ observado com o projeto neoliberal de sociedade leva a crer que os dispositivos para permanência do ritmo concentrador devam ser continuamente reiterados para a tentativa de equilíbrio do ciclo de acumulação do capital em uma pequena parcela da população mundial. No Brasil, a concentração de renda e riqueza marca a trajetória brasileira, que registrou entre os anos 1980 e 2000, o crescimento econômico pífio, a piora na distribuição da riqueza se tornou mais forte e centrada em apenas quatro cidades do país (São Paulo, Rio de Janeiro, Brasília e Belo Horizonte), com cerca de $80 \%$ das famílias ricas do país (POCHMANN, 2010). Portanto, a análise das políticas educacionais não pode prescindir da compreensão da dinâmica econômica que progressivamente aprofunda as desigualdades sociais, sendo a presença do Estado fundamental para ajustar os fortes desequilíbrios sociais. 
Nos últimos anos, o Brasil tem os instrumentos de intervenção pública marcados pela concentração dos recursos destinados à população mais carente, pelo repasse de parte dos fundos públicos ao setor privado e pela descentralização das açóes por meio de uma rede de múltiplos programas de atenção aos problemas sociais.

Em especial, as políticas educacionais para a juventude foram significativas, não obstante contraditórias e com limites de ordem financeira. Do ponto de vista dos marcos legais, foram muitos os avanços conquistados no ensino médio como direito à educação básica, são eles: a Lei no 12.061, de 27 de outubro de 2009 (BRASIL, 2009a), que alterou o inciso II do art. 4 e o inciso VI do art. 10 da Lei no 9.394/96 (BRASIL, 1996), para assegurar o acesso de todos os interessados ao ensino médio público. Antes o Estado tinha como dever assegurar uma progressiva extensão da obrigatoriedade e gratuidade ao ensino médio; com a nova lei, o Estado deve assegurar a universalização do ensino médio gratuito. A Emenda Constitucional no 59, de 11 de novembro de 2009 (BRASIL, 2009b), que acrescenta o $\$ 3^{\circ}$ ao art. 76 do Ato das Disposiçóes Constitucionais Transitórias para reduzir, anualmente, a partir do exercício de 2009, o percentual da Desvinculação das Receitas da União (DRU) incidente sobre os recursos destinados à manutenção e ao desenvolvimento do ensino de que tratava o art. 212 da Constituição Federal, deu nova redação aos incisos I e VII do art. 208, de forma a prever a obrigatoriedade do ensino de 4 a 17 anos. Importa ainda destacar a promulgaçáo do Fundo de Manutenção e Desenvolvimento da Educaçáo Básica e de Valorização dos Profissionais da Educação (Fundeb), que estendeu a política financeira de fundos para o ensino médio e a educação de jovens e adultos (EJA).

Como forma de materializaçáo da legislaçáo que visa ampliar o acesso e a melhoria da escolaridade aos jovens, o governo federal implantou, em 2005, o Programa Ensino Médio Integrado (EMI) e o Programa Nacional de Integração da Educação Profissional com a Educação Básica na Modalidade de Educação de Jovens e Adultos (Proeja). Ambos os programas têm por princípio pedagógico o trabalho como princípio educativo. Essa proposta significa, acima de tudo, ter o aluno no centro do processo formativo, mas sua implantação passa por diversos problemas de gestáo pedagógica e financeira, de acordo com pesquisas desenvolvidas no âmbito do Observatório da Educação (OBEDUC) (CAPES/PROEJA/SETEC, 2012). Ademais, o número de matrículas nesses programas é pouco expressivo, tendo em vista a totalidade de alunos matriculados no ensino médio e na EJA. Em 2013, o Proeja atendia 61,5 mil estudantes, sendo dois terços concentrados no ensino médio e o restante no ensino fundamental. A matrícula total da EJA nesse mesmo ano foi de 1.324.878 pessoas. O EMI, em 2013, contava com 312.122 matrículas - um número pequeno dentro de um total de matrículas da ordem de 8.312 .815 jovens.

Também foi criado, em 2011, o Programa Nacional de Acesso ao Ensino Técnico e Emprego (Pronatec), com uma concepção de formaçáo e de quali- 
ficação contrária aos programas citados anteriormente. O Pronatec integra várias ações e tem uma estreita parceria com instituiçôes privadas. Foi nesse programa que houve maior investimento financeiro do governo brasileiro, o que fez ter um crescimento de 5,8\% no total de matrículas na educaçáo profissional no biênio 2012-2013, alcançando o patamar de 1,4 milhão de matrículas nas modalidades subsequente, concomitante e integrada ao ensino médio. Nesse período foi observado também um encolhimento da oferta pela rede pública (IPEA, 2015). Os estudos de Ribeiro (2014) destacam que o Pronatec é um programa de inclusão dos excluídos, cujo objetivo é garantir a oferta de mão de obra com baixos salários e, também, traduz uma medida para reduzir a pressáo por elevaçóes salariais e tornar viável a expansão das relaçóes capitalistas.

A expansão da educação superior ocorreu por meio de iniciativas governamentais implantadas a partir da segunda metade da década de 1990, com grande incentivo nos setores privados, como, por exemplo, o Fundo de Financiamento Estudantil (Fies) e o Programa Universidade para todos (ProUni). Após 2003, especificamente no setor público, houve a expansão da rede federal. Mesmo assim, em 2013, as instituições públicas de ensino superior correspondiam a 29\% das matrículas nos cursos de graduação presenciais. Ademais, uma proporção significativa dos estudantes matriculados nas instituiçóes privadas tinha o benefício de algum tipo de subsídio público. "Grosso modo, poder-se-ia afirmar que apenas $47,3 \%$ das matrículas nestes cursos eram de natureza genuinamente privada" (IPEA, 2015, p. 226).

Os dados da PNAD/IBGE mostram que as políticas de acesso ao ensino superior conseguiram aumentar a participaçáo dos jovens de baixa renda na educação superior. Tais políticas de democratização são associadas às açóes afirmativas onde se inserem as cotas e o ProUni, as quais se tornaram um percurso obrigatório para compensar a pobreza instaurada no quadro social de profundas desigualdades historicamente constituídas.

Mas nada indica que temos implantado políticas para a igualdade da educação, pois observamos que a inclusão dos jovens à escolarização básica e superior é resultado de políticas construídas sobre o princípio da desigualdade legítima e não sob o princípio da igualdade do exercício dos direitos. Essa prática consiste essencialmente em tentar incluir um conjunto de jovens com limitaçóes sociais em instituições educacionais estruturadas de forma desigual e excludente.

Mas, como lembra Castel (1992), falar em exclusão é folhear uma qualificação puramente negativa que designa a falta sem dizer o que ela consiste, nem de onde provém. Essa análise tem como pano de fundo o contexto de crise do Estado-providência, iniciada na década de 1970 em diversos países europeus, que introduziu princípios do mercado nos programas sociais. Até então, a política educativa estava fundada sobre um consenso entre os social-democratas, de que deveriam regular e financiar a educação com vistas à igualdade de chances. Mas essa 
política mudou. Com o olhar sob a experiência inglesa, Tomlinson (2009) destaca que a educação passou do status de pilar do Estado-providência para sustentar uma economia de mercado mundializada e de instrumento a serviço de um Estadomercado a desenvolver.

A partir de estudos comparativos entre sete países europeus, Frandji e Rochex (2011) afirmam que nos anos 1990 as políticas buscaram minimizar o objetivo de luta contra as desigualdades de aprendizagem em nome da luta contra a exclusão. Essa reformulação está ligada ao advento dos novos problemas sociais e de novas preocupaçóes fortemente mediatizadas pelo desemprego, das violências escolares e urbanas, e das saídas precoces do sistema escolar sem diploma. Segundo os autores, a utilização da categoria "grupos de risco" para definir o público que vai receber as políticas focalizadas se compreende nesse sentido. Essa mudança se explicitou sobretudo na Inglaterra, sob a ação dos governantes do new labour. A posição mais elaborada é de menos engajamento para promover a igualdade do que para combater a exclusão social e promover a inclusão. Portanto, a noção de inclusão social aplicada pelo new labour implica na criação não mais de uma sociedade igualitária, mas de uma sociedade que todos os cidadãos teriam um acesso garantido ao nível mínimo de bem-estar social e se sentissem assim incluídos dentro de uma mesma comunidade.

Na mesma direção, Derouet (2003) afirma que a igualdade da educação, que esteve junto com o direito ao trabalho e à proteçáo social formando os pilares do Estado-providência, foi substituída pela luta contra a exclusão. Para ele, a discussão hoje não é mais sobre a igualdade de chances, mas sobre a igualdade de resultados. Essa constatação pode ser observada em várias partes da educação mundial com a presença dos sistemas de avaliaçáo em larga escala, inclusive no Brasil. Toda avaliação constrange o Estado a elaborar um conhecimento prévio de desigualdades que ele entende legítimo no sistema educativo, de maneira a estabelecer um principio de comparação ou de equivalência entre os seres, ou de qualidades a ela relacionada (NORMAND, 2009).

Os países membros da OCDE alcançaram a igualdade no direito à educação, pois a oferta escolar se dá relativamente de forma equânime quando se analisa as estruturas físicas e financeiras das escolas. Mas a igualdade de chances é ainda um grande desafio para a educação desses países. De fato, a cada dia que passa se apresenta como uma ilusão liberal, conforme analisado por Bourdieu e Passeron (1970). A cada ano na França, 140 mil jovens com mais de 16 anos (1 aluno sobre 10) abandonam a escola sem diploma ou o brevet do collège (MONNERAIS, 2015) 7 .

$\mathrm{Na}$ República Brasileira, a prática da igualdade de direitos foi dificultada desde o seu início, porque além da forte concentração da riqueza nacional em uma pequena parte da população, a institucionalização da educação contou sempre com a forte presença do setor privado na oferta do ensino. Além da divisão real 
provocada pela oferta pública e privada do ensino em acordo com as classes sociais, o valor que o privado tem no corpo da sociedade brasileira define uma ordem de grandeza que, no geral, orienta os sentidos de justiça social. Cada vez mais é exigido dos jovens do ensino superior que procurem os financiamentos privados para assegurar o seu diploma. Mas a seleção, a diversidade e a desigualdade na oferta do trabalho não asseguram aos jovens uma inserção positiva nas diferentes escalas do mundo do trabalho.

Podemos pensar, a partir dessa ideia, que as políticas educacionais são orientadas para dar um suposto equilíbrio razoável entre a inclusão e a exclusão dos jovens, já que não existe um projeto que integra o conjunto das açóes econômicas e sociais diretamente ligado aos problemas enfrentados pelos jovens na sociedade globalizada. Mas, sobretudo, não podemos dizer que neste século as políticas públicas foram implantadas como meios de neutralizar os efeitos das desigualdades sociais sobre as desigualdades escolares. Por exemplo, a aplicação de políticas afirmativas não significa a afirmação de um direito crescente à igualdade de chances para todos e garantido pela escola; ao contrário, é o reconhecimento da desigualdade de chances e a necessidade de implantaçâo de contrapartidas compensatórias. $\mathrm{O}$ tratamento da exclusão não revela a mesma forma de ação pública que orienta as políticas sociais inspiradas pela luta contra as desigualdades.

Geralmente, é a noção de equidade que orienta tais açôes políticas sobre a defesa de um pluralismo de concepçôes de justiça social. A abordagem de Rawls (2011) serve de modelo para muitas políticas a partir da ideia de que é justo aquilo que resulta de um processo justo. No entanto, a equidade náo implica necessariamente igualdade no sentido onde cada um deveria receber uma parte igual, isto é, mensurável e comparável à parte recebida pelo outro. A equidade é o produto da justa apreciação do que é dado a cada um, segundo um princípio superior de justiça (GARNIER, 2009). Para Rawls (2011), a equidade de um sistema educativo não deve ser avaliada somente por critérios internos, mas deve levar em consideração os efeitos sociais. Com a defesa pela justiça com equidade, Rawls entende que as políticas devem repassar benefícios aos membros menos privilegiados.

Essa ideia pode ser identificada nas políticas de inclusão que, no caso da educação brasileira, é realizada com baixo investimento dos fundos públicos. Trata-se de uma preocupação centrada na inibição de uma maior exclusão social ou no reconhecimento de uma desigualdade legítima, mas sem políticas organicamente planejadas entre as várias esferas institucionais para garantir a igualdade no exercício dos direitos sociais. Essa prática gera um grande prejuízo para a população matriculada nas escolas, pois historicamente suas estrutura e gestão se constituíram de forma desigual e precária. Muitas vezes, em uma mesma cidade, podemos observar o funcionamento de escolas públicas em bons prédios e equipamentos adequados para o desenvolvimento da aprendizagem, mas também existem escolas funcionando sem as mínimas condiçóes para a manutençáo e o desenvolvimento do trabalho pedagógico. 
A tese de Algebaile (2009) revela que a expansão escolar, promovida desde a década de 1990 no Brasil, serviu como meio de operar um encurtamento da esfera pública no campo educacional e no da política social. A escola que chega aos pobres tem uma funcionalidade gerada a partir do entendimento de que a educação é um fator minimizador de riscos e de tensóes sociais. Segundo a autora, foi considerado desnecessário implementar um sistema de ensino sofisticado e, sim, utilizar a estrutura da rede de escolas públicas para a prestação de serviços de assistência social, com o objetivo de atenuar a pobreza.

Os avanços quantitativos observados no processo de expansão da educação pública são reconhecidos por Cury (2008) a partir da expressão "inclusão excludente", porque conquanto despidos de uma qualidade, apresentam uma opção preferencial pelas classes populares. "A face manifesta dessa inclusão excludente é a privação de determinados direitos e bens sociais para ser, ao mesmo tempo, precariamente incluído em outras dimensóes da produção da existência social (CURY, 2008).

A análise de Cury (2008) parte da problematizaçáa do conceito de exclusão colocada por Martins (2002), para quem a exclusão "fala de situaçóes objetivas de privação, mas não nos fala tudo nem nos fala o essencial" (MARTINS, 2002, p. 43). Portanto, o termo não provoca a luta por transformaçóes sociais, mas pode mesmo negar a história. Como bem sintetiza Castel (1995), a exclusão emana de uma ordem de razóes proclamadas, ou seja, ela não é arbitrária e sim legitimamente reconhecida, produto de procedimentos oficiais que representam um verdadeiro status.

Boltanski e Chiapello (2009) sublinham que a exclusão se apresenta como um destino (contra o qual é preciso lutar), e não como resultado de uma assimetria social da qual certas pessoas tirariam proveito em prejuízo de outras. Para eles, a exclusão ignora a exploração, mas essa noção é uma forma de exploração que se desenvolve num mundo conexionista, ou seja, num mundo no qual a realizaçáo do lucro passa por atividades em rede. Nesse mundo, cada um vive na angústia permanente de ser desconectado, ficar entregue à própria sorte, abandonado no local por aqueles que se deslocam. Por isso, Foucauld (1992) questiona se exclusão e desigualdade são ou não da mesma natureza. Para ele, a exclusão é de outra natureza e não pode constituir exploração porque a exploração ocorre no trabalho e os excluídos caracterizam-se principalmente por estarem privados do trabalho. Ao mesmo tempo, é preciso uma abordagem que integra exclusão e desigualdade dentro de uma ótica de coesão social em uma sociedade dinâmica. Talvez a ideia de uma desigualdade legítima seja o elo adotado atualmente como referência às convençôes de validade geral quanto àquilo que é justo ou injusto.

Touraine (1992) vai afirmar que existe uma consciência crescente da exclusão porque estamos cada vez mais em uma sociedade que domina o pensamento liberal, em termos de mercado. E como é uma sociedade que integra mais 
do que antigamente, ela também tem uma capacidade de exclusão superior, pois as duas coisas estão ligadas. Na sociedade pós-industrial, segundo Touraine (1992), todos são obrigados a ganhar. A compreensão dos fenômenos sociais mais visíveis não é em termos de desigualdade, mas em termos de justiça. Ou seja, é preciso colocar mecanismos que assegurem um mínimo de justiça e de regras no jogo. A ideia subjacente é do fim da utopia da igualdade.

Para Crahay (2000), a igualdade de chances morreu; há que trabalhar no estabelecimento de uma justiça corretiva na escolaridade básica. O princípio "cada qual com as suas capacidades" deve ser substituído pelo "a cada qual as suas necessidades". Enquanto a escola se atribuir a missão de estabelecer os fundamentos cognitivos, volitivos e culturais, necessários a qualquer indivíduo para ter o seu lugar integral de cidadão na nossa sociedade moderna, ela tem o dever de visar à igualdade dos adquiridos. Esse imperativo moral não é incompatível com o respeito pelas diferenças, pelo menos de algumas. Mas, seria possível se aproximar da igualdade de chances ao fortalecer a igualdade da oferta escolar entre os diversos grupos sociais?

Nada indica, segundo Dubet, Duru-Bellat e Vérétout (2010), que a escola faz crescer a igualdade de chances para todo mundo. As hierarquias escolares podem ser também rígidas como as hierarquias sociais e pode ser que elas não sejam justas, mesmo que legítimas. Nada indica que as competências escolares são úteis à atividade social. Elas podem classificar os indivíduos, selecionar as elites e excluir os menos competentes. Quanto aos valores e às atitudes desenvolvidas pela escola, elas não são necessariamente um bem coletivo, pois as sociedades mais educadas não são automaticamente mais tolerantes, mais prazerosas e mais coesas. Não dá para pensar que a sociedade pode mudar pelas práticas e políticas escolares. Tudo vai depender da maneira como as sociedades utilizam as qualificaçóes escolares. Portanto, em matéria de integração social, as características da sociedade, notadamente seu nível de riqueza e de dinamismo, sáo mais decisivas para alcançar a justiça social do que as características dos sistemas escolares.

\section{Escolarização de jovens no início do século XXI}

O compromisso pela democratização do acesso ao ensino no Brasil nas últimas duas décadas produziu resultados efetivos para as juventudes. Ao mesmo tempo não deixou de apontar também para uma forma massificada de seus resultados.

De um lado, o sinal positivo evidenciado pelos números que mostram o crescimento inegável da escolarização dos jovens brasileiros na virada para o século XXI, uma vez que o segmento de 15 a 29 anos de idade com acesso aos ensinos médio e superior foi multiplicado 2,6 vezes. No ano de 2013, por exemplo, mais de $64,0 \%$ do segmento etário de 15 a 29 anos possuía pelo menos o acesso ao ensino médio do país, ao passo que em 1992 eram apenas 24,4\% do total (Gráfico 1). 
Para o mesmo período, a população brasileira de 15 a 29 anos de idade aumentou 9,1 milhões, ou seja, crescimento acumulado de 22,9\% (1,0\% como média anual). Desse acréscimo populacional, 7,1 milhóes assumiram a condição de estudante, o que significou que a cada grupo de 10 pessoas entre 15 e 29 anos de idade, 8 se matricularam no ensino brasileiro (Gráfico 2).

A taxa de estudantes entre o segmento etário de 15 a 29 anos cresceu $37,7 \%$ no acumulado entre 1992 e 2013 (1,5\% ao ano, em média). Mas a maior

\section{Gráfico 1}

Brasil: evolução da composição da escolaridade da população total de 15 a 29 anos entre 1992 e 2013 (em \%).

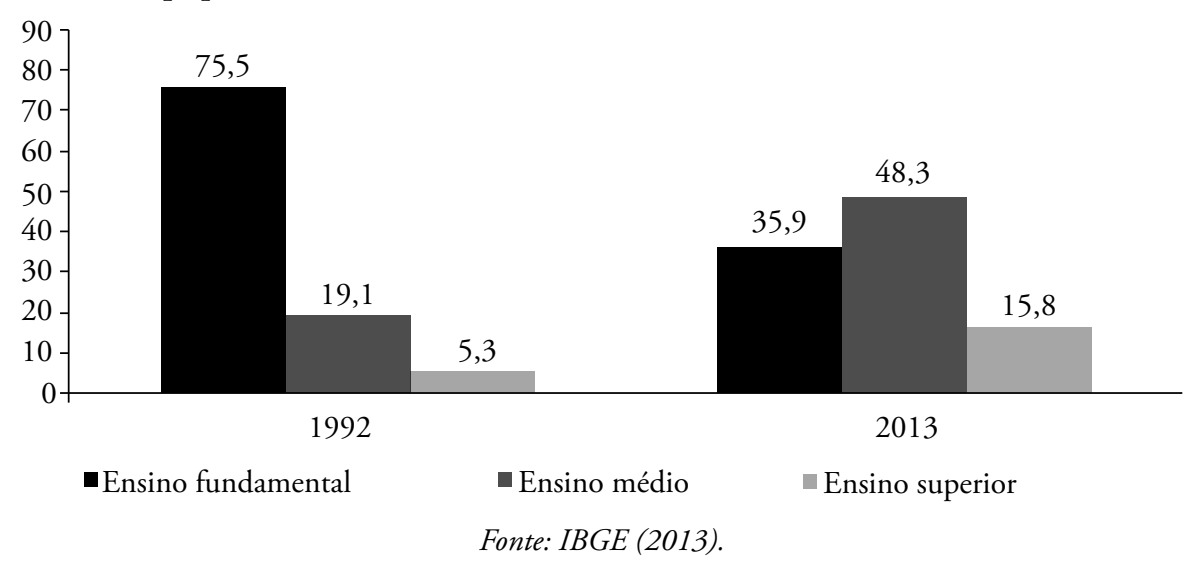

\section{Gráfico 2}

Brasil: evolução da participação dos estudantes na

população total de 15 a 29 anos de idade entre 1992 e 2013 (em \%).

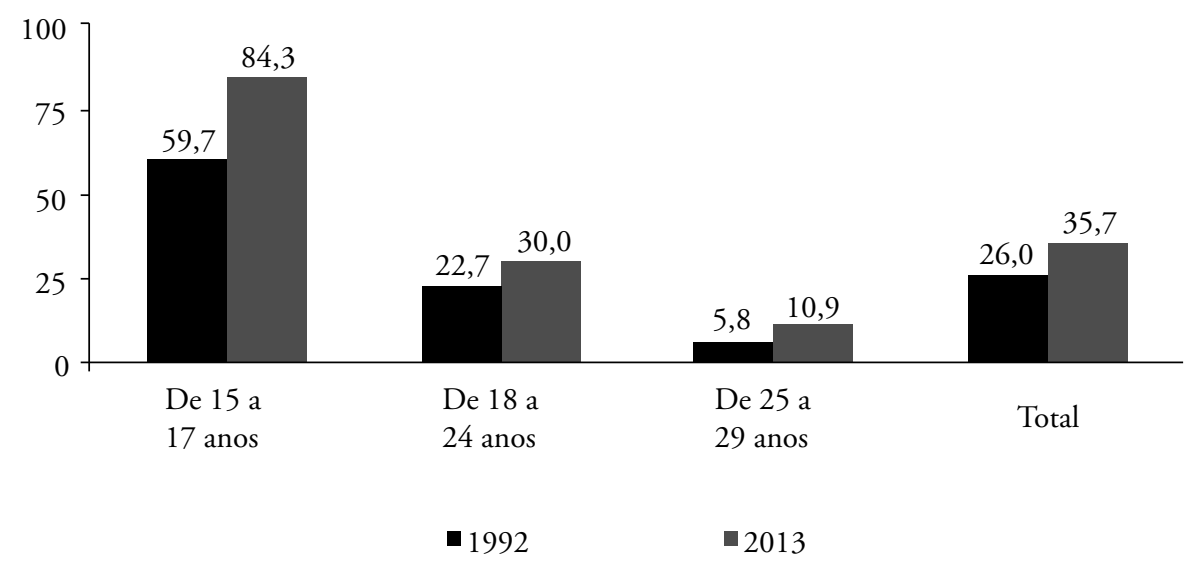

Fonte: IBGE (2013). 
expansão no acesso ao ensino ocorreu na faixa etária de 25 a 29 anos (87,9\%), pois passou de apenas $5,8 \%$ do total das pessoas desse mesmo segmento etário em 1992 para 10,9\% em 2013. Na sequência, observa-se a elevação acumulada da taxa de estudantes entre a população de 15 a 17 anos (41,2\%), seguida de 32,2\% de crescimento na faixa etária de 18 a 24 anos (Gráfico 3).

Dentro da perspectiva de elevaçáo da taxa de escolarização do segmento juvenil brasileiro neste início do século XXI, constata-se a leve expansão da presença do gênero masculino. Isso porque em 1992, por exemplo, 50,7\% dos estudantes de 15 a 29 anos de idade eram do sexo feminino, ao passo que no ano de 2013 esse número foi reduzido para $50,1 \%$ do total. Ou seja, uma queda acumulada de $1,2 \%$, ainda que o sexo seja levemente superior ao masculino.

A queda mais pronunciada na presença feminina no total dos estudantes ocorreu na faixa etária de 15 a 17 anos. A menor reduçáo foi verificada na faixa etária de 25 a 29 anos de idade (Gráfico 4).

Outro aspecto importante a ser assinalado na evolução da escolarização juvenil decorre do crescimento da participaçáo de náo brancos (indígena, preta, amarela e parda) no total da população estudantil. Em 2013, por exemplo, 43,2\% dos estudantes se declararam de cor/raça branca ao IBGE, enquanto em 1992 eram $52,7 \%$, o que representou queda acumulada de $18,0 \%$ no período considerado.

A maior queda na participação da raça/cor branca foi verificada na faixa etária de 25 a 29 anos de idade (20,4\%). A menor diminuição ocorreu, entretanto, na faixa etária de 18 a 24 anos (16,8\%), pois no segmento de 15 a 17 anos houve redução de 18,1\% entre os anos de 1992 e 2013.

\section{Gráfico 3}

Brasil: evolução da presença feminina no total dos estudantes de 15 a 29 anos de idade entre 1992 e 2013 (em \%).

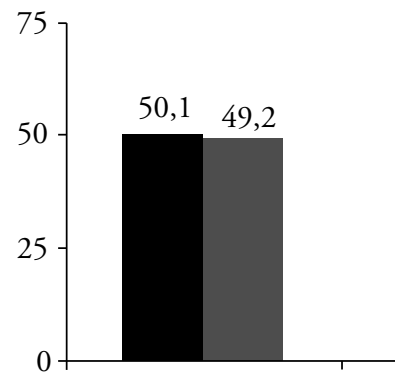

De 15 a 17 anos

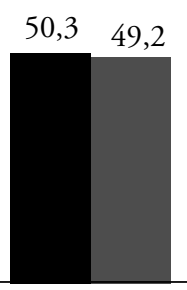

De 18 a 24 anos

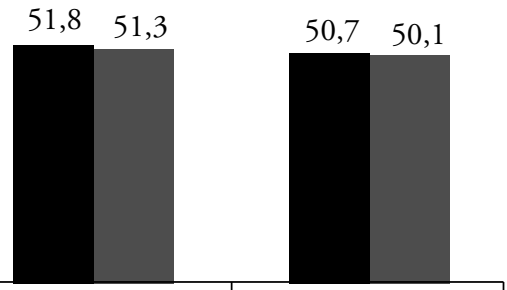

De 25 a

29 anos

Total 
Para o mesmo período de tempo, cabe ainda considerar a evolução da escolarizaçáo segundo as diferentes faixas de rendimentos. Quando se toma como referência, por exemplo, o estrato estudantil que representa os $40 \%$ de domićlios mais pobres, percebe-se uma leve elevação em sua participaçáo relativa. No ano de 2013, a presença dos 40,0\% mais pobres no segmento estudantil foi de 38,0\%, enquanto que em 1992 era de $37,1 \%$. Ou seja, aumento acumulado de 2,4\% em 21 anos (Gráfico 5).

\section{Gráfico 4}

Brasil: evolução da presença de pessoas de cor/raça branca no total dos estudantes de 15 a 29 anos de idade entre 1992 e 2013 (em \%).

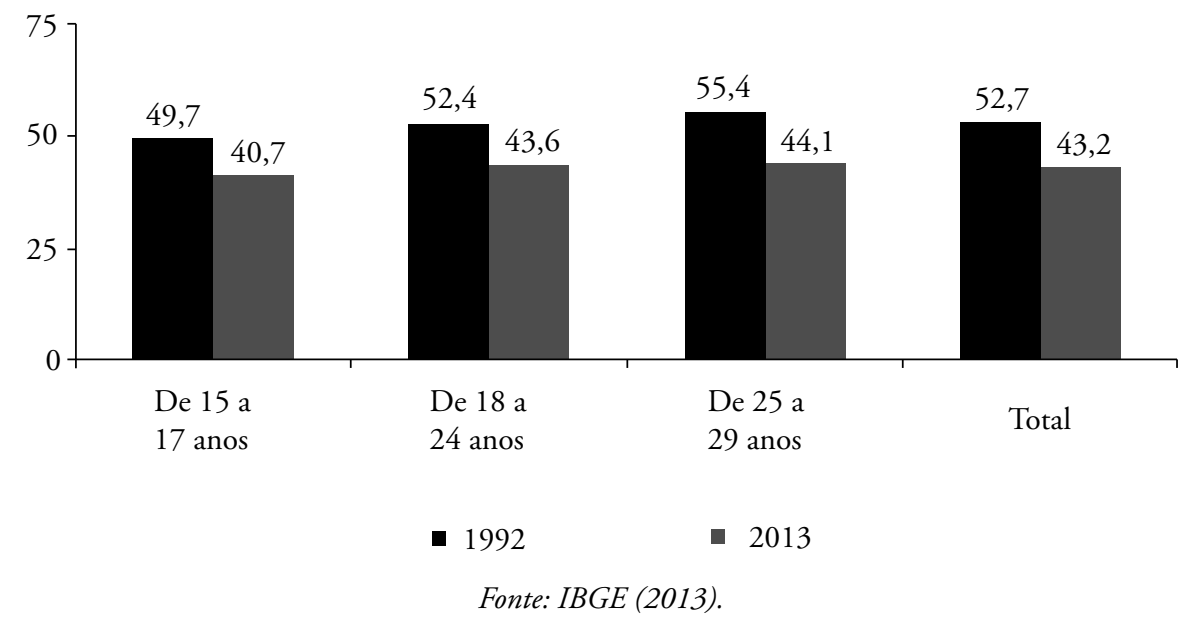

\section{Gráfico 5}

Brasil: evolução da participação dos $40 \%$ mais pobres no total dos estudantes de 15 a 29 anos de idade entre 1992 e 2013 (em \%).

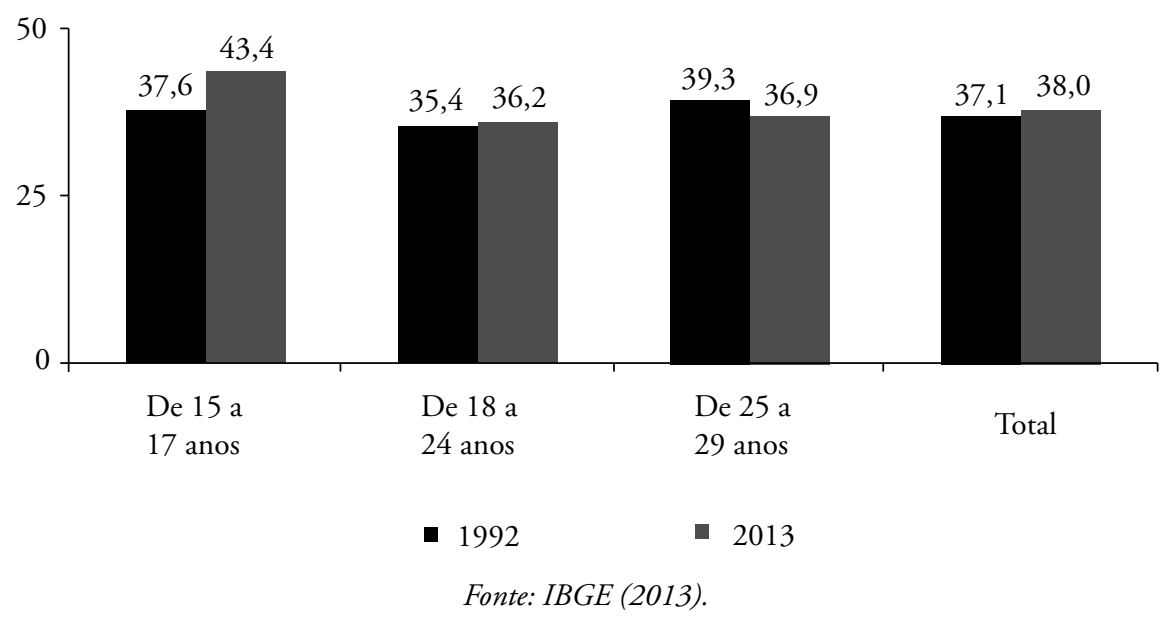


O maior aumento no peso relativo do segmento mais pobre na população estudantil ocorreu no segmento etário de 15 a 17 anos (15,4\%). No segmento de 25 a 29 anos, contudo, houve reduçáo relativa na presença do segmento de menor rendimento (6,1\%) no período de 1992 a 2013 (Gráfico 6).

No caso do segmento estudantil de maior nível de rendimento, também se constata crescimento em sua participação relativa. Entre 1992 e 2013 houve a ampliação de $6,5 \%$ na participação relativa dos $20 \%$ mais ricos na população estudantil, pois passou de $18,5 \%$ do total para $19,7 \%$.

A queda somente ocorreu no segmento etário de 15 a 17 anos (6,6\%), uma vez que aumentou nas demais faixas etárias. No período analisado, o crescimento foi de $6,6 \%$ no segmento etário de 18 a 24 anos e de $14,7 \%$ para a faixa etária de 25 a 29 anos (Gráfico 7).

Diante da expansão relativa dos extremos da distribuiçáo da renda ( $40 \%$ mais pobres e $20 \%$ mais ricos) no total da população estudantil, constata-se a compressão do estrato de rendimento intermediário. Assim, quando se considera o segmento de $40 \%$ de rendimento abaixo dos $20 \%$ mais ricos e de rendimento acima dos $40 \%$ mais pobres na população estudantil, observa-se a sua redução relativa.

No ano de 2013, por exemplo, os 40,0\% de rendimento intermediário respondiam por $42,3 \%$ do total do segmento estudantil de 15 a 29 anos de idade, enquanto em 1992 era de 44,4\%. Em síntese, uma queda acumulada de 4,7\% em 21 anos analisados. A diminuição mais intensiva ocorreu na faixa etária de 15 a 17 anos (10,3\%) e a mais intensa no estrato de 25 a 29 anos (0,9\%) (Gráfico 8).

\section{Gráfico 6}

Brasil: evolução da participação dos $20 \%$ mais ricos no total dos estudantes de 15 a 29 anos de idade entre 1992 e 2013 (em \%).

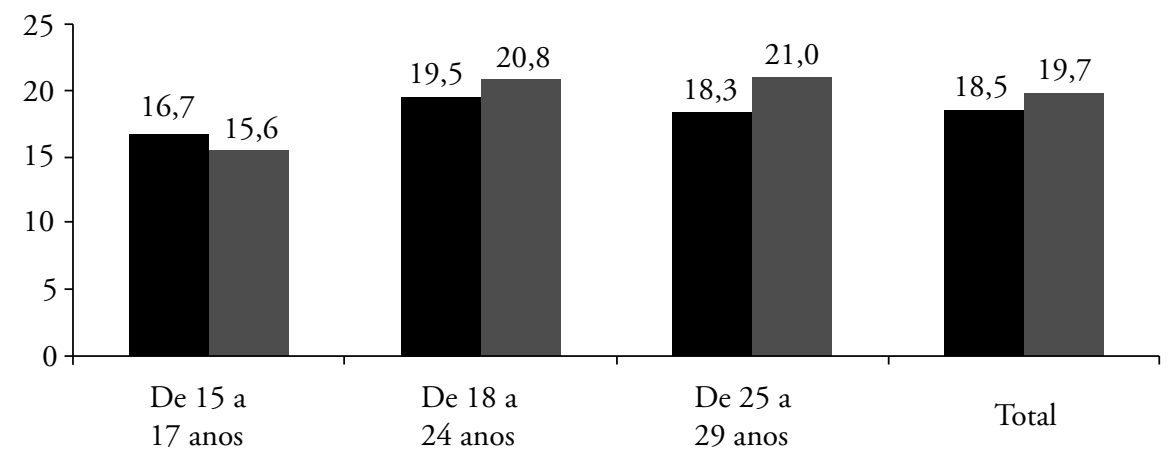


Além disso, observa-se também que a elevação da escolaridade juvenil foi acompanhada da queda na taxa de abandono do ensino. Na faixa etária de 15 a 17 anos, por exemplo, a taxa de abandono caiu 38,6\% entre os anos de 2007 e 2013 (Gráfico 9).

Em relação ao acesso à educação brasileira, percebe-se que para o segmento etário de 15 a 17 anos, a escola pública foi a mais importante, uma vez que a taxa de escolarizaçấo aumentou levemente entre 2002 (86,5\%) e 2013 (87,6\%). Para as faixas de idade superiores, a presença relativa de estudante na rede pública

\section{Gráfico 7}

Brasil: evolução da participação dos $40 \%$ de rendimento intermediário no total dos estudantes de 15 a 29 anos de idade entre 1992 e 2013 (em \%).

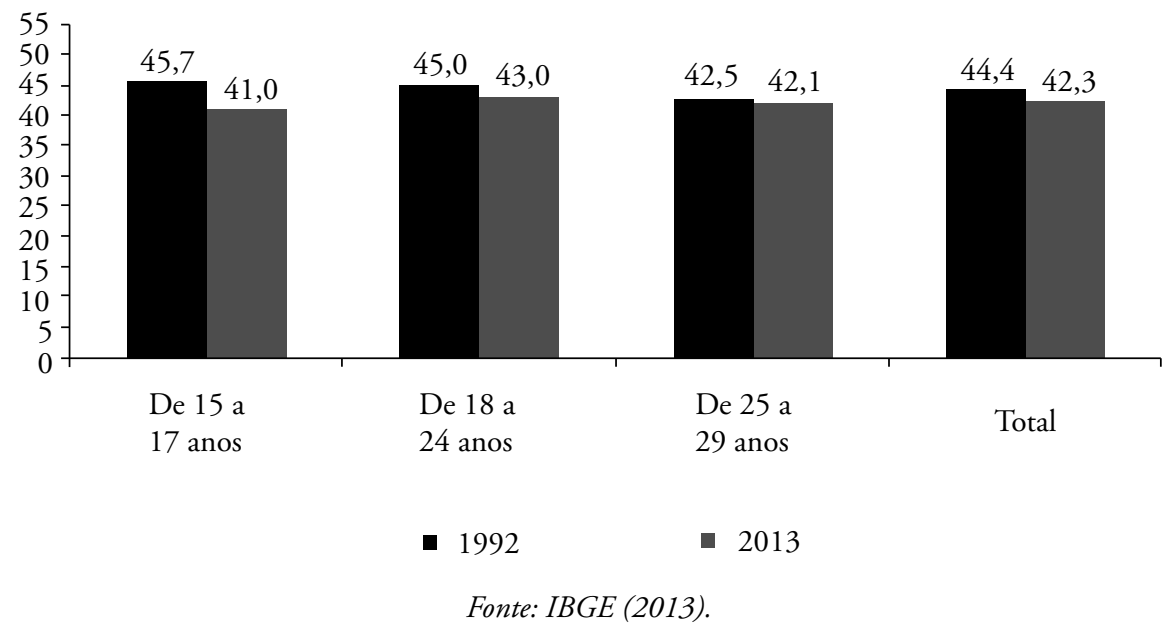

\section{Gráfico 8}

Brasil: evolução da taxa de abandono do ensino médio na faixa etária de 15 a 17 anos de idade (em \%).

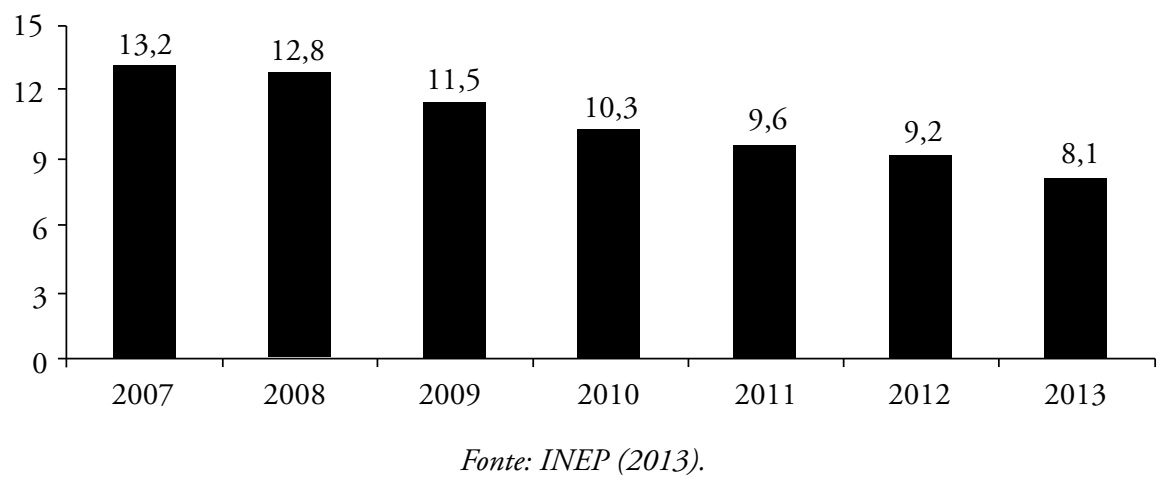


de ensino foi reduzida em $17,9 \%$ entre 18 a 24 anos e de $38,1 \%$ de 25 a 29 anos. Para as faixas etárias de 15 a 29 anos, a queda na presença relativa da escola pública foi de 7,6\% (Gráfico 10).

Outro aspecto significativo a revelar decorre da elevação da inatividade entre os estudantes na faixa etária de 15 a 29 anos de idade. No ano de 2013, qua-

\section{Gráfico 9}

Brasil: evolução da participação dos estudantes na população total de 15 a 29 anos de idade matriculados nas escolas públicas entre 1992 e 2013 (em \%).

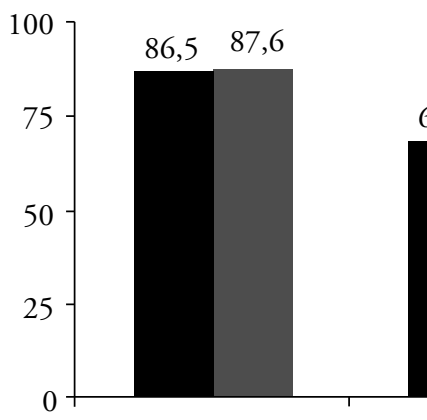

De 15 a

17 anos

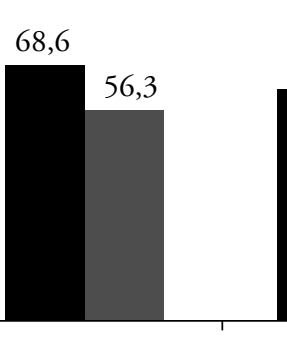

De 18 a

24 anos

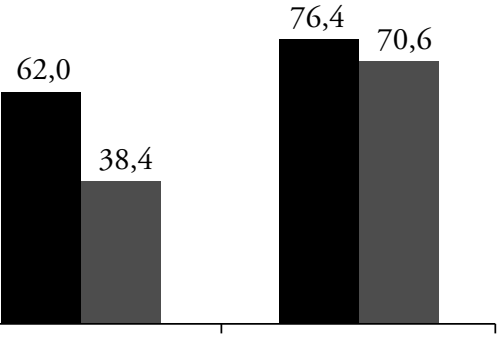

De 25 a

29 anos

Total

2002

- 2013

Fonte: IBGE (2013).

\section{Gráfico 10}

Brasil: evolução da taxa de inatividade na população total de 15 a 29 anos entre 1992 e 2013 (em \%).

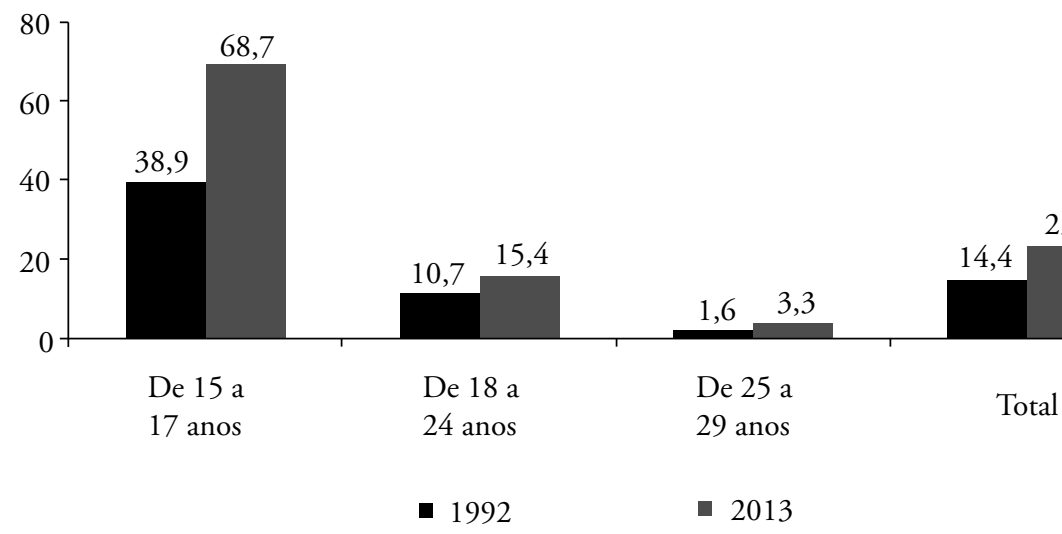

Fonte: IBGE (2013). 
se $69,0 \%$ do segmento de 15 a 17 anos encontrava-se na condição de estudante, ante praticamente $39,0 \%$ em 1992 , o que representou aumento de $76,6 \%$ no mesmo período de tempo.

$\mathrm{Na}$ faixa etária de 18 a 24 anos, o crescimento foi de 43,9\%, permitindo que a parcela que estudava passasse de $10,7 \%$ para $15,4 \%$. E, por fim, na faixa etária de 25 a 29 anos, a parte que estudava passou de 1,6\% para 3,3\%, com aumento de 106,2\% entre os anos de 1992 e 2013. Para as faixas etárias de 15 a 29 anos como um todo, o aumento dos estudantes na condição de inatividade foi de $60,4 \%$ (Gráfico 11).

Entre os ocupados também houve elevação de escolaridade entre os jovens. No ano de 2013, menos de $29,0 \%$ das pessoas ocupadas de 15 a 29 anos de idade encontravam-se situados no ensino fundamental, ao passo que em 1992 compreendiam quase $80 \%$ do total (queda de 61,3\%). Tais dados podem mostrar que o crescimento da populaçáo jovem no ensino médio e superior, acompanhado da diminuição da populaçáo de 15 a 17 anos de idade no ensino fundamental, revelaria o investimento dos jovens na escolaridade sob a ilusão da igualdade de chances.

Em contrapartida, a participação do segmento de 15 a 29 anos no ensino médio foi multiplicada 2,6 vezes, saltando de 19,6\%, em 1992, para 50,9\%, em 2013. Para o ensino superior, a presença dos jovens com o ensino superior passou de $6,3 \%$ para $20,4 \%$ no mesmo período de tempo (multiplicado 3,2 vezes).

A expansão da parcela da juventude com acesso ao ensino foi acompanhada tanto do aumento na taxa de inatividade como da queda na taxa de ocupação. Entre 1992 e 2013, por exemplo, a taxa de ocupados caiu 5,5\%, pois passou de $60,9 \%$ para $55,4 \%$.

\section{Gráfico 11}

Brasil: evolução da composição da escolaridade dos ocupados de 15 a 29 anos entre 1992 e 2013 (em \%).

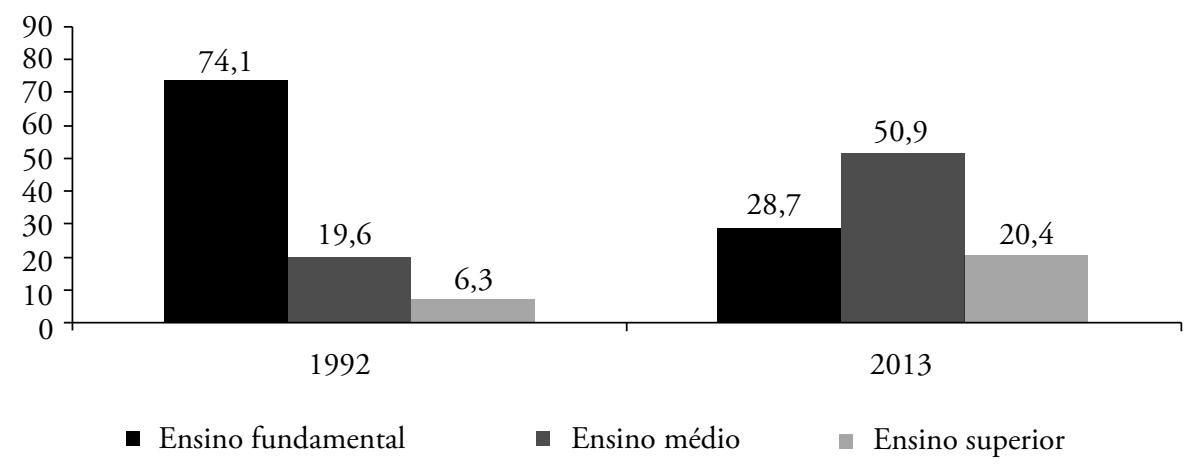

Fonte: IBGE (2013). 
A maior queda na taxa de ocupação ocorreu na faixa de 15 a 17 anos (54,1\%), uma vez que em 2013 havia $21,0 \%$ dos jovens que estavam ocupados, ante $46,0 \%$ em 1992. Também houve diminuição na taxa de ocupados entre jovens de 18 a 24 anos de 3,5\% entre os anos de 1992 e 2013 . Somente na faixa etária de 25 a 29 anos de idade houve elevaçáo na taxa de ocupação, de 3,5\% no mesmo período de tempo (Gráfico 12).

Se considerado o conjunto de jovens que não estudam, o comportamento da taxa de ocupação não foi muito distinto, apenas mais intenso. Ocorreu queda na taxa de jovens ocupados de 78,9\% para faixa etária de 15 a 17 anos e de $12,1 \%$ entre 18 e 24 anos; e inalteração para o segmento de 25 a 29 anos de idade. Para o conjunto dos jovens que não estudam, na faixa de 15 a 29 anos, a diminuição na taxa de ocupação entre 1992 e 2013 foi de 13,2\% (Gráfico 13).

Diante disso, constatou-se também a mudança significativa na composiçâo da escolaridade entre os jovens desempregados de 15 a 29 anos de idade. Aqueles jovens desempregados com o ensino fundamental deixaram de representar mais de $78,0 \%$ do total, em 1992, para chegar em 44,8\% em 2013 (queda acumulada de 42,6\%) (Gráfico 14).

Entre os jovens desempregados com ensino médio na faixa etária de 15 a 29 houve aumento de quase 150,0\% entre 1992 e 2013. Para o ensino superior, o crescimento relativo dos jovens desempregados foi ainda maior (multiplicado 2,7 vezes), pois passou de 3,7\% para 10,1\% no mesmo período de tempo.

Em relação aos jovens de 15 a 29 anos que não estudam, constata-se a taxa de desempregados de 12,6\% entre os anos de 1992 e 2013. Nos distintos segmentos etários juvenis, a taxa de desemprego decaiu diferenciadamente (Gráfico 15).

\section{Gráfico 12}

Brasil: evolução da taxa de ocupação na população total de 15 a 29 anos entre 1992 e 2013 (em \%).

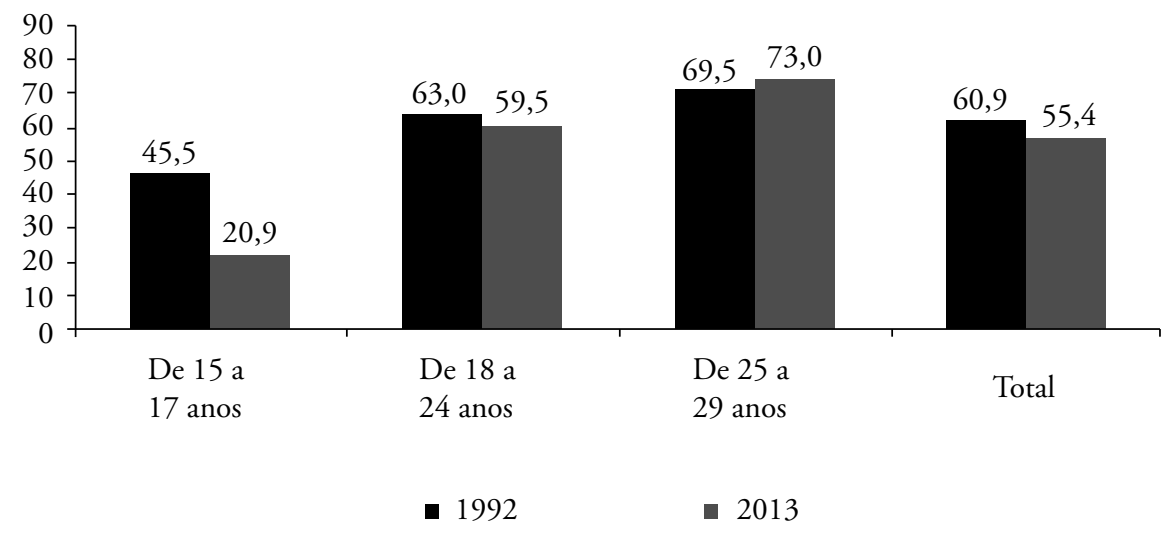

Fonte: IBGE (2013). 
Para a faixa etária de 15 a 17 anos, por exemplo, a taxa de desemprego de jovens que não estudam caiu 33,3\% entre 1992 e 2013 . Nesse mesmo período de tempo, os jovens de 18 a 25 anos de idade que náo estudam registram diminuição na taxa de desemprego de 4,6\%.

$\mathrm{Na}$ faixa de 25 a 29 anos de idade, a taxa de desemprego dos que náo estudam foi reduzida em 18,0\% entre os anos de 1992 e 2013. Para o conjunto dos jovens de 15 a 29 anos de idade que não estudam, a taxa de desemprego caiu $12,6 \%$ no mesmo período de tempo.

\section{Gráfico 13}

Brasil: evolução da taxa de ocupados que não estudam na população total de 15 a 29 anos entre 1992 e 2013 (em \%).

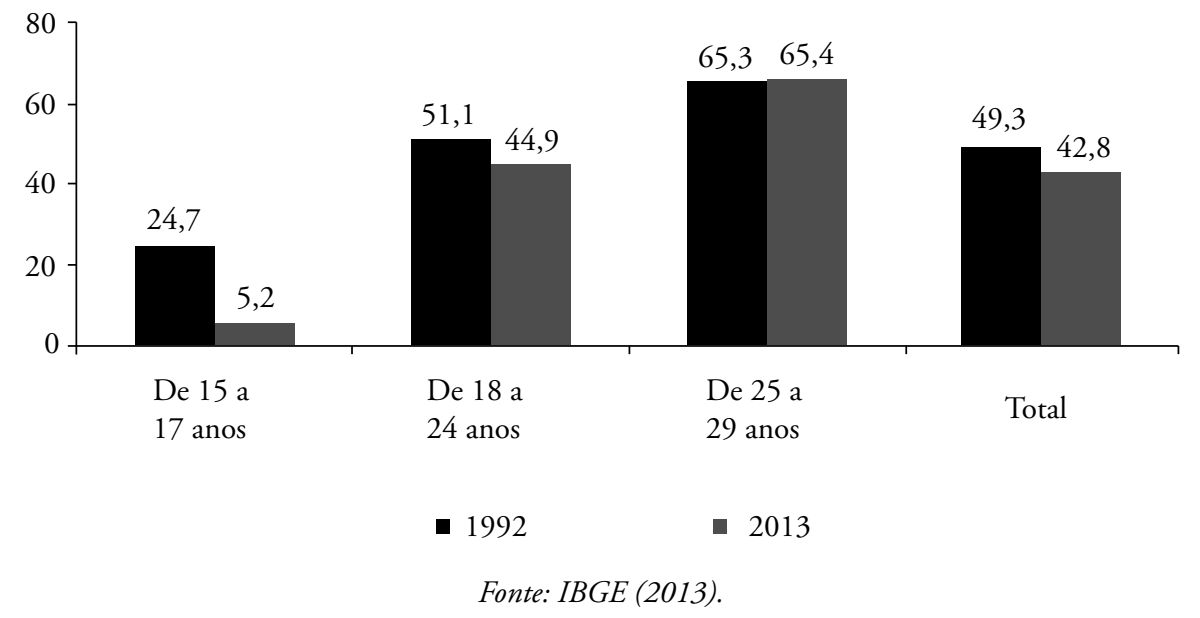

\section{Gráfico 14}

Brasil: evolução da composição da escolaridade dos desempregados de 15 a 29 anos entre 1992 e 2013 (em \%).

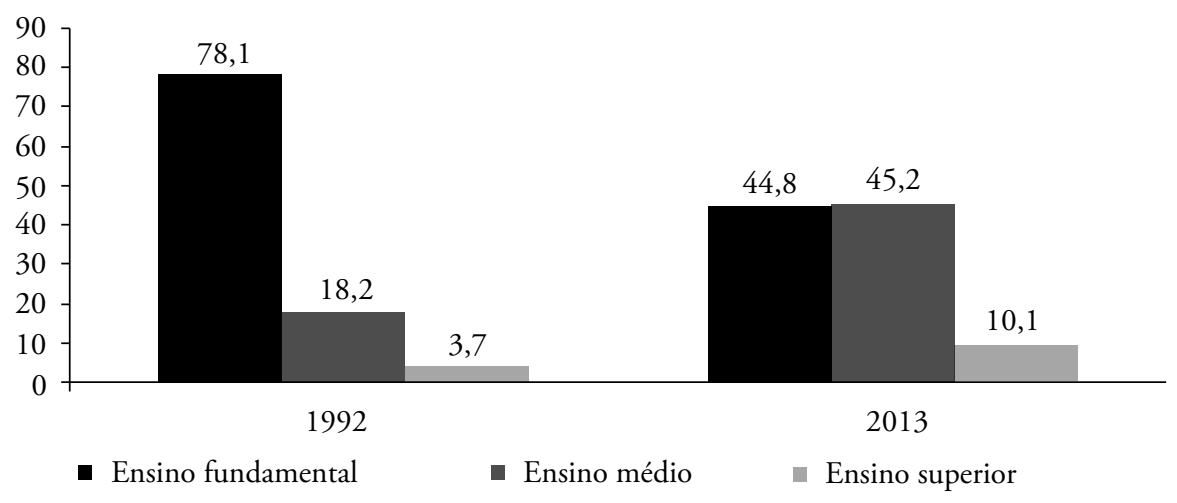

Fonte: IBGE (2013). 
Desse conjunto sistematizado de informaçóes a respeito dos jovens brasileiros, percebe-se considerável aumento da escolarização acompanhada da maior inatividade. Com isso, a postergaçâa do ingresso da juventude no mercado de trabalho, especialmente daqueles pertencentes às famílias de menor rendimento, ampliou a oportunidade da disputa em torno do emprego de melhor qualidade, até entâo reservado àqueles que estudavam por mais tempo, geralmente filhos de pais de alta renda.

Apesar disso, constata-se também a mudança significativa na composição do desemprego, agora mais concentrado entre os jovens de maior escolaridade. Sem a geraçáo de empregos de maior qualidade pelo país, jovens escolarizados são expostos ao maior desemprego e ao acirramento da competição no interior do mercado de trabalho ${ }^{8}$.

Os dados também apontam para a permanência da desigualdade no acesso à escolaridade, em que pese o fato de apresentar uma elevação de $15,4 \%$ entre a população mais pobre de 15 a 17 anos de idade. É provável que o crescimento da escolaridade nessa faixa etária seja resultado de uma demanda contida, mas essa porcentagem ainda é pequena em face o número de jovens sem escolaridade no Brasil. Conforme destacado anteriormente, em 2013, cerca de 16 milhóes de jovens brasileiros não se encontravam formalmente habilitados a pleitear uma vaga na educação superior. Na faixa etária de 18 a 24 anos de idade, 31,0\% dos jovens não haviam concluído o ensino médio e não estavam estudando. Em relação ao acesso ao ensino superior, do total de estudantes brancos de 18 a 24 anos, $69,4 \%$ frequentavam o ensino superior. Mas entre os jovens estudantes pretos ou pardos,

\section{Gráfico 15}

Brasil: evolução da taxa de desempregados que não estudam na população total de 15 a 29 anos entre 1992 e 2013 (em \%).

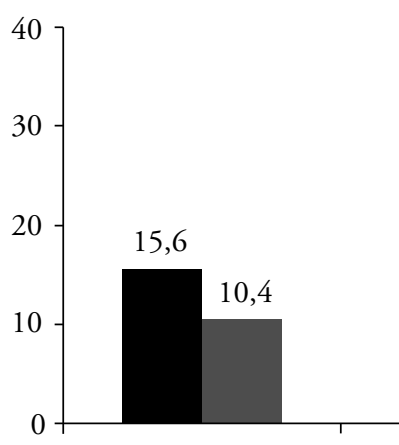

De 15 a

17 anos

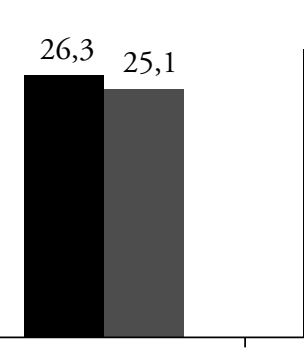

De 18 a

24 anos

28,9

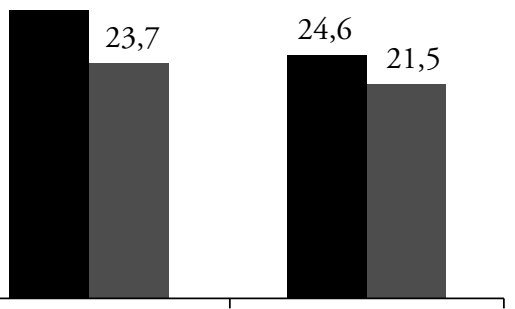

De 25 a

29 anos

Total

- 1992

- 2013

Fonte: IBGE (2013). 
apenas $40,7 \%$ cursavam o mesmo nível, não obstante o crescimento ocorrido da participação de não brancos (indígena, preta, amarela e parda) no total da populaçáo estudantil nos 21 anos aqui pesquisados.

Portanto, o período pós-constituição brasileiro aqui analisado revela que o processo de inclusão promovido por meio de políticas educacionais não se mostra suficiente para promover uma igualdade de oportunidades. A queda da participaçấo na escola, de 6,1\% no segmento mais pobre de 25 a 29 anos, reforça essa tese em face ao crescimento de 6,6\% no segmento etário de 18 a 24 anos e de $14,7 \%$ para a faixa etária de 25 a 29 anos de idade no segmento mais rico da sociedade brasileira.

Esses dados, por mais que sejam ainda pouco conclusivos porque precisariam de maiores cruzamentos com outros indicadores sociais, levam a questionar as virtudes da educação escolar sobre a integração e a coesão social, pois não há razão para crer que as sociedades sejam diretamente transformadas pelas políticas educacionais. Pelo contrário, as relaçóes entre os sistemas escolares e as sociedades são bem mais complexas e muito incertas. Em geral, a escola não é concebida como justa pelos jovens porque seu acolhimento é fraco no sentido dos valores que desenvolve, mais parecidos com a lógica da empresa, e também o diploma não representa uma inserção qualificada no mercado de trabalho. Como afirmado anteriormente, as políticas educacionais renunciaram ao ideal de igualdade de chances, sendo estabelecidas no limite do alcance de um suposto equilíbrio entre a inclusão e a exclusão dos jovens na sociedade globalizada e "conexionista".

Ao mesmo tempo, na ausência da universalização do acesso a uma educação de qualidade socialmente referenciada, especialmente aos jovens pertencentes às famílias de menor rendimento, a desigualdade mantém-se ativa. Da mesma forma que a elevaçáo da escolaridade distante da geração de empregos de qualidade tende a manter desigual a situação social relativa à ascensão no mercado de trabalho brasileiro.

\section{Considerações finais}

Mesmo com os esforços dos governos na ampliação da matrícula no ensino médio, cujo marco central foi a Emenda Constitucional no 59 (BRASIL, 2009b), que assegurou o direito à educaçáo para a populaçáo de 4 a 17 anos de idade, o número de jovens com diploma é baixo em relaçáo à população de 15 a 29 anos de idade. Sáo 51.340.478 indivíduos (IBGE, 2010), sendo que muitos não chegaram a procurar a escola, outros tantos abandonaram os estudos de forma a náo completar a educaçáo básica e uma pequena porcentagem seguiu os estudos no ensino superior. A hipótese de maior aceitaçáo no meio acadêmico sobre esse problema é da existência de fatores intraescolares próprios de uma instituição burocrática e disciplinar que geram o fracasso escolar, combinado a fatores externos vinculados à pobreza e à fragilidade das políticas educacionais. 
Certamente tais questóes fazem parte de um mosaico complexo de situaçóes e condiçóes, as quais podemos entender sob o ponto de vista da racionalidade dominante que privilegia políticas educacionais sob a perspectiva de garantir a escolaridade na vida dos jovens como mecanismo de individualizar o problema da desigualdade como um feito da (in)capacidade do jovem na aquisiçáo do diploma. Dessa maneira, ela acentua não somente a reprodução social, mas também coloca um efeito negativo sobre a coesão social.

Nos marcos do sistema capitalista, na atualidade da visão "conexionista" do mundo social, o modelo europeu de igualdade de chances se mostrou uma ilusão. Em alguma medida, o Brasil incorporou esse ideal, sobretudo na perspectiva da Teoria do Capital Humano do período da ditadura militar. Mas podemos afirmar que esse ideal não se configurou em políticas educacionais concretas para a escola básica pública e a presença da escola privada teve um papel significativo nessa configuração. Não obstante, isso não foi impedimento para a introdução do direito à educação, consagrando uma expansão da escolaridade da população, agora sob a lógica dos resultados. Os dados mostram que as políticas educacionais dos últimos anos conseguiram engajar grande parte dos jovens na escola, sendo o diploma o mecanismo para legitimar a concorrência, a condição do emprego e a justificação do não emprego.

Ao mesmo tempo, as análises indicam que não podemos mais julgar o que é justo em função do que é igual. A generalização de medidas nas políticas educativas, as medidas de taxas de sucesso nos exames, a medida de uma categoria social ter acesso a um nível escolar, a comparação de medidas de performance de sistemas educativos de diferentes países etc. substituíram a referência à igualdade pela referência à justiça social. Este artigo entende que esse é um debate que precisa ser aprofundado pelas pesquisas no campo das políticas educacionais.

\section{Notas}

1. A desigualdade fundamenta e caracteriza o desenvolvimento das sociedades capitalistas. As políticas de igualdade, em contrapartida, partem de pressupostos teóricos constituídos a esse respeito. Sobre isso, ver Keslassy (2003), Pfefferkorn e Bihr (1999).

2. Para eles, o espírito do capitalismo é o conjunto de crenças associadas à ordem capitalista que contribuem para justificar e sustentar a ordem, legitimando os modos de ação e as disposiçóes, sejam elas gerais ou práticas, locais ou globais, expressas em termos de virtude ou em termos de justiça, que dáo respaldo ao cumprimento de tarefas mais ou menos penosas e, de modo geral, à adesão a um estilo de vida, em sentido favorável à ordem capitalista. O primeiro espírito do capitalismo terá sido aquele que foi abordado por Max Weber; o segundo espírito do capitalismo é do keynesianismo e do Estado-providência. 
3. O projeto é a oportunidade e o pretexto para a conexão. Ele reúne temporariamente pessoas muito diferentes e apresenta-se como um segmento de rede fortemente ativado durante um período relativamente curto, mas que permite criar laços mais duradouros, que permanecerão adormecidos, mas sempre disponíveis (BOLTANSKI; CHIAPELLO, 2009, p. 135).

4. Para maior aprofundamento a respeito do tema justiça/injustiça, ver Walzer (1997), Rawls (2011) e Sen (1992).

5. Podemos entender tais conceitos a partir de Dubet, Duru-Bellat e Vérétout (2010): a integração consiste em descrever os sistemas sociais e os sistemas escolares pela distribuiçấo objetiva das posições sociais. A coesão é definida pelas atitudes, pelos valores e pelas disposições favoráveis à cooperação, à confiança e à tolerância.

6. Piketty (2014) reuniu, em um trabalho exaustivo de coleta de informaçôes sobre tributos, heranças e registros de salários, uma série histórica mostrando que, em praticamente todos os países do mundo desenvolvido, ocorreu aumento da desigualdade, que havia caído entre a primeira e a segunda guerras, e voltou a subir a partir da década de 1980. Os mecanismos de redistribuição da riqueza são fracos vis-à-vis à força dos mecanismos de sua concentração.

7. Disponível em: <http://www.alterecoplus.fr/societe/le-decrochage-scolaire-ce-fleau-201503230600-00001032. html $>$. Acesso em: 21 maio 2015.

8. Na primeira década do século XXI, por exemplo, $95,0 \%$ dos 21 milhóes de novos postos de trabalho foram de até 1,5 salário mínimo mensal ante 34,5\% dos 17,2 milhóes de novas vagas abertas na década de 1970. Para maiores detalhes sobre a evoluçâo do saldo das ocupaçôes segundo faixa de remuneração, ver Pochmann (2012).

\section{Referências}

ALGEBAILE, E. Escola pública e pobreza no Brasil: a ampliação para menos. Rio de Janeiro: Lamparina, 2009.

BOLTANSKI, L.; CHIAPELLO, È. O novo espírito do capitalismo. São Paulo: Martins Fontes, 2009.

BOURDIEU, P.; PASSERON, J. La reprodution. Paris: Minuit, 1970.

BRASIL. Lei no 9.394, de 20 de dezembro de 1996. Estabelece as diretrizes e bases da educação nacional. Diário Oficial da União, Brasília, DF, p. 27833, 23 dez. 1996. Seção 1.

. Lei no 12.061 , de 27 de outubro de 2009a. Altera o inciso II do art. $4^{\circ}$ e o inciso VI do art. 10 da Lei no 9.394, de 20 de dezembro de 1996, para assegurar o acesso de todos os interessados ao ensino médio público. Diário Oficial da União, Brasília, DF, p. 1, 28 out. 2009. Seção 1.

Emenda Constitucional no 59, de 11 de novembro de 2009b. Acrescenta $₫ 3^{\circ}$ ao art. 76 do Ato das Disposiçóes Constitucionais Transitórias para reduzir, anualmente, a partir do exercício de 2009, o percentual da Desvinculaçáo das Receitas da Uniáo incidente sobre os recursos destinados à manutenção e desenvolvimento do ensino de que trata o art. 
212 da Constituição Federal, dá nova redação aos incisos I e VII do art. 208, de forma a prever a obrigatoriedade do ensino de quatro a dezessete anos e ampliar a abrangência dos programas suplementares para todas as etapas da educação básica, e dá nova redação ao $\$ 4^{\circ}$ do art. 211 e ao $\$ 3^{\circ}$ do art. 212 e ao caput do art. 214, com a inserçáo neste dispositivo de inciso VI. Diário da Câmara dos Deputados, Brasília, DF, v. 198, p. 63047, 12 nov. 2009.

COORDENAÇÃO DE APERFEIÇOAMENTO DE PESSOAL DE NÍVEL SUPERIOR, PROGRAMA NACIONAL DE INTEGRAÇÃO DA EDUCAÇÃO PROFISSIONAL COM A EDUCAÇĀO, NA MODALIDADE DE JOVENS E ADULTOS, SECRETARIA DE EDUCAÇÃO PROFISSIONAL E TECNOLÓGICA DO MINISTÉRIO DA EDUCAÇÃO - CAPES/PROEJA/SETEC. Educação profissional no ensino médio: desafios da formação continuada de educadores na educação de jovens e adultos no âmbito do PROEJA no Espírito Santo. Vitória: UFES, 2012.

CASTEL, R. De l'exclusion comme état à la vulnérabilité comme processus. In: AFFICHARD, J.; FOUCAULD, J. Justice sociale et inégalités. France-Quercy: Éditions Esprit, 1992. p. 135-148.

. As metamorfoses da questão social: uma crônica do salário. Rio de Janeiro: Vozes, 1995.

CRAHAY, M. L'école peut-elle être juste et efficace? De l'égalité des chances à l'égalite des acquis. Bruxelles: Boeck e Lancier, 2000.

CURY, C.R.J. A educação básica no Brasil. Educação \& Sociedade, Campinas, v. 23, n. 80, p. 168-200, 2002.

A educação escolar, a exclusão e seus destinatários. Educação em Revista, Belo Horizonte, n. 48, p. 205-222, 2008.

DEROUET, J. Le collège unique en question. Paris: PUF, 2003.

DEROUET, J.; DEROUET-BESSON, M. (Ed.). Repenser la justice dans le domaine de l'éducation et de la formation. Allemagne: Peter Lang SA/INRP, 2009.

DEROUET, J.L.; DEROUET-BESSON, M.C. (Eds.). Repenser la justice dand le domaine de l'education et de la formation. Bern: Peter Lang, 2009, p. 171-186.

DUBET, F.; DURU-BELLAT, M.; VÉRÉTOUT, A. Les sociétés et leur école: emprise du diplôme et cohésion sociale. Paris: Seuil, 2010.

FOUCAULD, J. Vouloir faire, savoir faire. In: AFFICHARD, J.; FOUCAULD, J. Justice sociale et inégalités. France-Quercy: Éditions Esprit, 1992.

FRANDJI, D.; ROCHEX, J.Y. De la lutte contre les inégalités à l'adaptation aux 'besoins spécifiques'. Éducation \& Formations, n. 80, p. 95-108, 2011.

GARNIER, B. Figures de l'égalité: deux siècles de thétoriques politiques en éducation (1750-1950). Belgique: Louvain-La-Neuve, 2009.

INSTITUTO BRASILEIRO DE GEOGRAFIA E ESTATÍSTICA - IBGE. Pesquisa Nacional por amostra de domicílio. Brasília: IBGE, 2013.

INSTITUTO DE PESQUISA ECONÔMICA APLICADA - IPEA. Politicas sociais: acompanhamento e análise. Número 23. Brasília: IPEA, 2015. 
INSTITUTO NACIONAL DE ESTUDOS E PESQUISAS EDUCACIONAIS ANÍSIO TEIXEIRA - INEP. Indicadores educacionais. Brasília: MEC, 2013.

KESLASSY, E. Démocratie et inégalité. Paris: Bréal, 2003.

MARTINS, J.S. Exclusão social e a nova desigualdade. São Paulo: Paulus, 2002.

MONNERAIS, T. Le décrochage scolaire, ce fléau! Disponível em: <http://www.alterecoplus. fr/priorite-jeunesse/le-decrochage-scolaire-ce-fleau-201503230600-00001032.html> Acesso em: 25 maio 2015.

NORMAND, R. Mesurer la justice en éducation: esquisse d'une arithmétique politique des inégalités. In: DEROUET, J.; DEROUET-BESSON, M. (eds.) Repenser la justice dans le domaine de l'éducation et de la formation. Allemagne: Peter Lang SA/INRP, 2009, p. 349-364.

PFEFFERKORN, R.; BIHR, A. Déchiffrer les inégalites. París: Syros, 1999.

PIKETTY, T. O capital do século XXI. São Paulo: Intrínseca, 2014.

POCHMANN, M. Desenvolvimento e novas perspectivas para o Brasil. São Paulo: Cortez, 2010. Nova classe média? São Paulo: Boitempo, 2012.

RAWLS, J. Uma teoria da justiça. Martins Fontes: Lisboa, 2011.

RIBEIRO, J. Pronatec diante da inclusão excludente e da privatização da formação. Revista Textual, Porto Alegre, v. 1, n. 19, p. 17-21, 2014.

SEN, A. Repenser linégalité. Paris: Bréal, 1992.

TELLES, V. Pobreza e cidadania: o avesso da cidadania. São Paulo: Editora 34, 1999.

TOMLINSON, S. Education et justice sociale dans une société de l'après Etat-providence. In: TOURAINE, A. Inégalites de la société industrielle, exclusion du marché. In: AFFICHARD, J.; FOUCAULD, J. Justice sociale et inégalités. France-Quercy: Éditions Esprit, 1992, p. 163-176.

WALZER, M. Sphères de la justice. Paris: Le Seuil, 1997.

Recebido em 29 de fevereiro de 2016.

Aprovado em 29 de setembro de 2016. 